\title{
Investigation of Convergence in the Returns of Cryptocurrencies: Panel Nonlinear Tar Approach
}

\section{Mustafa ÖZYEŞIL iDa}

a İstanbul Aydın University, Anadolu Bil Vocational School, , İstanbul, Turkey. mozyesil@aydin.edu.tr

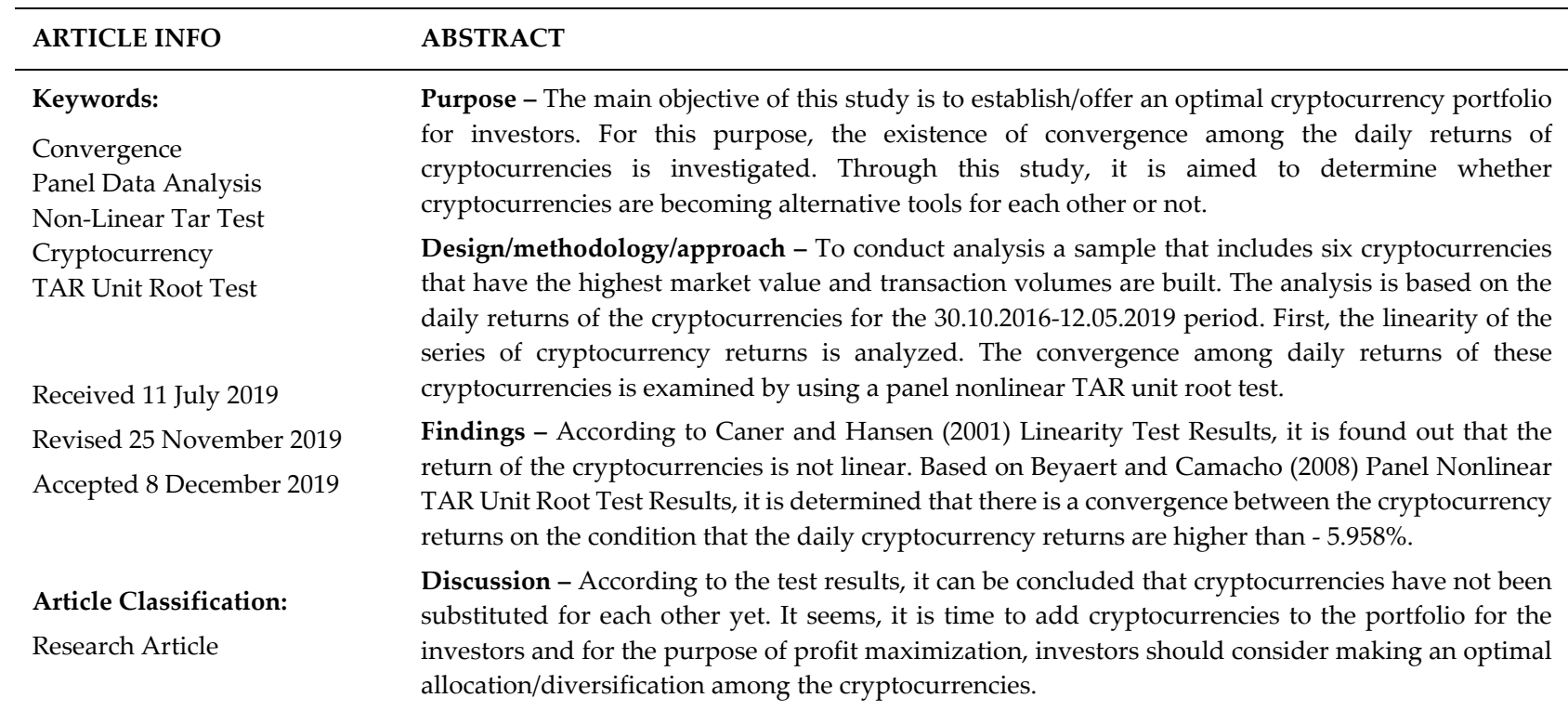

\section{Introduction}

Nowadays, the concept of cryptocurrency has attracted the attention of all countries, and it is one of the most talked-about topics in the financial world. When compared to traditional government-issued paper money, cryptocurrencies are accepted digital alternatives by providing some advantages such as ensuring transactions are secure, avoid people to use the same account balance more than once, and thanks to being decentralized they enable quasi-anonymous transactions (Luther, 2016: 553). All these advantages of cryptocurrencies can explain their intensively increasing popularity.

The first example of the concept of cryptocurrency is Bitcoin. BITCOIN was developed in 2008 by a person or people whose nickname is Satoshi Nakamoto. Bitcoin is a peer to peer digital currency, and it is not based on central authority (Nakamoto, 2008).

Extreme volatile price changes that occurred in Bitcoin have also been another factor that attracted the interest of the financial community to cryptocurrency. Recently increased interest in Bitcoin boosted its price even over $\$ 20,000$ for a short time and valued Bitcoin more than $\$ 300$ billion (Dyhrberg et al., 2013:140).

Because of these remarkable movements in the price of BITCOIN, the issue of cryptocurrency has attracted significant interest, and therefore similar cryptocurrencies have been issued. According to the trading economics web site, as of May 2019, the number of cryptocurrencies currently in circulation is around 2,500. As a result of all these developments, this subject has attracted the attention of countries. While some countries conduct legal arrangements regarding the prohibition or authorization of cryptocurrencies, others are in the process of issuing their cryptocurrencies. 
Convergence is playing a crucial role in order to find asymptotic distributions of estimators. Convergence is the expression used to make the accuracy of the results of statistical analysis acceptable. This is a case that is the observation of numerical expressions that are the closest to each other by comparing results obtained at the end of the calculations and accepting closest to average as a correct result.

Based on whether there is a convergence among the daily returns of the cryptocurrencies, it will be understood that these cryptocurrencies become substitutes for each other or not. As a result, it will shed light on the decision-makers regarding the portfolio selection model over the cryptocurrencies.

Therefore, in this study, the existence of convergence between the daily returns of the cryptocurrencies included in the sample is examined, and it is determined whether these cryptocurrencies are substitutes for each other. Based on findings also it is tried to developed suggestions for the investors who will form portfolios through these cryptocurrencies.

\section{Literature Review}

Beyaert and Camacho (2008), examined the existence of a convergence in terms of national income per capita among European Union countries by nonlinear TAR unit root test for 1950-2004 period. As a result of the analysis, it was determined that there was convergence of income among $15 \mathrm{EU}$ member countries, but the convergence disappeared when Eastern European countries are included in this group.

Beyaert and García-Solanes (2009) examined the existence of national income convergence in two group countries in the period of 1950-2007 by nonlinear TAR unit root test according to the shape of conjuncture curves. They found that the convergence of income was stronger among the countries in the middle regions of the conjuncture curve. They also found that the convergence of income disappeared in the peak region of the conjuncture curve for rich countries or in the bottom region of the conjuncture curve for poor countries.

Çil, Yavuz and Yılancı (2013) examined the existence of convergence between G7 countries in terms of CO2 emission by nonlinear TAR unit root test. They found that the series was nonlinear and conditional convergence under Regime I and divergence under Regime II among G7 countries at the point of CO2 release. Dikmen and Dursun (2018) examined the validity of the unemployment hysteresis hypothesis in Latin American countries by using nonlinear TAR unit root test using data from 1980-2015 period. According to the results of the analysis, it is determined that the unemployment hysteresis hypothesis in these countries is valid under Regime I. When researchers examined the existence of a convergence of unemployment in these 12 Latin American countries they found out that there ise divergence under regime I and absolute convergence under regime II.

\section{Data and Sample}

In this study, the existence of a convergence between the daily returns of cryptocurrencies was analyzed by using data of Bitcoin, Litecoin, Ripple, Ethereum, Ethereum Classic and Zcash for the period of 30.10.201612.05.201

Cryptocurrencies with the longest data set were preferred when determining the sample. The data were obtained from investing.tr website. Descriptive statistics of the data set are provided in Table 1.

Table 1: Descriptive Statistics of Sampling

\begin{tabular}{|l|c|c|c|c|c|c|}
\hline & BITCOIN & RIPPLE & ETHEREUM & $\begin{array}{c}\text { ETHEREUM } \\
\text { CLASSIC }\end{array}$ & LITECOIN & ZCASH \\
\hline Mean & 0,341 & 0,802 & 0,498 & 0,456 & 0,573 & 0,030 \\
\hline Median & 0,321 & $\begin{array}{c}- \\
0,276\end{array}$ & - & $\begin{array}{c}- \\
0,192\end{array}$ & $\begin{array}{c}- \\
0,256\end{array}$ & - \\
\hline Maximum & 25,559 & 179,546 & 29,511 & 70,391 & 83,488 & 172,112 \\
\hline Minimum & - & - & - & - & - & - \\
\hline Std. Dev. & 4,051 & 47,951 & 23,404 & 29,105 & 26,505 & 68,190 \\
\hline
\end{tabular}


M. Özyeşil 11/4 (2019) 3018-3024

\begin{tabular}{|l|c|c|c|c|c|c|} 
Skewness & 0,263 & 7,196 & 0,577 & 1,417 & 3,155 & 6,268 \\
\hline Kurtosis & 6,819 & 109,438 & 5,827 & 15,052 & 28,604 & 116,409 \\
\hline Jarque-Bera & 572,810 & $444.627,300$ & 359,314 & $5.907,594$ & $26.801,810$ & $501.762,300$ \\
\hline Probability & - & - & - & - & - & - \\
\hline Sum & 315,390 & 742,192 & 460,596 & 421,819 & 530,009 & 28,018 \\
\hline $\begin{array}{l}\text { Sum Sq. } \\
\text { Dev. }\end{array}$ & $17.172,160$ & $97.883,260$ & $34.747,020$ & $49.073,180$ & $50.633,730$ & $86.466,070$ \\
\hline \begin{tabular}{l} 
Observations \\
\hline
\end{tabular} & 925,000 & 925,000 & 925,000 & 925,000 & 925,000 & 925,000 \\
\hline
\end{tabular}

According to Table 1, the average returns of all cryptocurrencies except for Zcash are close to each other. The difference between Zcash and Ripple's lowest and highest value is quite high, while in other currencies this difference is relatively small. The number of observations used in the analysis is 925 and this is sufficient for a reliable panel data analysis.

\section{Method}

In the literature, convergence analyzes are performed through two different methods: In the first method, the stationarity of the series is examined and it is assumed that there is a convergence in the related variable when the series is stationary (Abbott, Vita ve Altınay, 2012; Erlat, 2012; Bahar, Bozkurt ve Doğan, 2013; Solarin, 2014; Solarin ve Lean, 2014; Barış Tüzemen ve Tüzemen, 2015; Savacı ve Karşıyakalı, 2016; Özcan ve Erdoğan, 2017; Alper ve Demiral, 2017; Yazgan, Ceylan ve Mollavelioğlu, 2018).

In the second method, regression analyzes are performed and it is decided by evaluating the regression coefficients are made on the obtained coefficients. In this method, the most widely used approaches are absolute $\beta$ convergence and conditional $\beta$ convergence (Mankiw, 1995; Karaca, 2004; Karaalp, 2008).

In this study, by employing the first approach, the existence of a convergence between the daily returns of cryptocurrencies are analyzed through the panel nonlinear TAR method. This method was developed by Beyaert and Camacho (2008) and was applied for the 12 European countries in order to determine whether their incomes are convergence. They found that there was convergence of income among 9 high-income countries but that when 3 low-income countries were included in the group, the convergence did not occur. In this test that is based on Threshold unit root test TAR structure, Beyaert and Camacho (2008) created the following regime equation in order to test the existence of convergence in terms of economic growth $(\mathrm{g})$ :

$$
\Delta g_{i t}=\left[\delta_{i}^{I}+\rho_{i}^{I} g_{i t-1}+\sum_{j=1}^{p} \varphi_{i j}^{I} \Delta g_{i t-j}\right] I_{\left\{Z_{t-1}<\lambda\right\}}+\left[\delta_{i}^{I I}+\rho_{i}^{I I} g_{i t-1}+\sum_{j=1}^{p} \varphi_{i j}^{I I} \Delta g_{i t-j}\right] I_{\left\{Z_{t-1} \geq \lambda\right\}}+\varepsilon_{i t}
$$

Where $i=1, \ldots, N ; t=1, \ldots, T ; I\{x\}$; It is an indicator that takes 1 when $\mathrm{x}$ is true, and 0 otherwise. When $Z_{t-1}<$ $\lambda$, Equation (1) will express Regime I and become as follows:

$$
\Delta g_{i t}=\rho_{i}^{I}+\rho_{i}^{I} g_{i t-1}+\sum_{j=1}^{p} \varphi_{i j}^{I} \Delta g_{i t-j}+\varepsilon_{i t}
$$

If $Z_{t-1} \geq \lambda$, then equation (2) will represent Regime II and will be shown as follows:

$$
\Delta g_{i t}=\rho_{i}^{I I}+\rho_{i}^{I I} g_{i t-1}+\sum_{j=1}^{p} \varphi_{i j}^{I I} \Delta g_{i t-j}+\varepsilon_{i t}
$$

Notations in the equation can be shown as follows:

$\lambda$ threshold parameter, 
$\mathrm{Z}$ is the transition variable and represents the shocks affecting the economy.

Hypothesis of this test (Beyaert and Camacho, 2008: 5).

$H_{0}: \rho_{i}^{I}=\rho_{i}^{I I}=0 \quad$ The Series Is Not Stationary (No Convergence).

$H_{1 A}: \rho_{i}^{I}<0, \rho_{i}^{I I}<0, \quad$ The Series Is Stationary (Full Convergence).

$H_{1 B}: \rho_{i}^{I}<0, \rho_{i}^{I I}=0$, The Series Is Stationary (Partial Convergence).

$H_{1 C}: \rho_{i}^{I}=0, \rho_{i}^{I I}<0$, The Series Is Stationary (Partial Convergence).

The test statistics required to test these hypotheses are obtained using the bootstrap cycle (Beyaert and GarciaSolanes, 2009). Beyaert and Camacho (2008) used the following statistics to determine which of the absolute or conditional convergences is valid in Equation (1):

$$
\begin{aligned}
\varphi_{a} & =\frac{1}{2 N-1}\left\{\sum_{i=1}^{N}\left[t\left(\delta_{i}^{I}\right)\right]^{2}+\sum_{i=1}^{N}\left[t\left(\delta_{i}^{I I}\right)\right]^{2}\right\} \\
\varphi_{b} & =\frac{1}{2 N-1}\left\{\sum_{i=1}^{N}\left[t\left(\delta_{i}^{I}\right)\right]^{2}\right\} \\
\varphi_{c} & =\frac{1}{2 N-1}\left\{\sum_{i=1}^{N}\left[t\left(\delta_{i}^{I I}\right)\right]^{2}\right\}
\end{aligned}
$$

In order to determine the existence of absolute or conditional convergence, the following conditions are taken into consideration (Dikmen and Dursun, 2018: 6):

When the $H_{1 A}$ hypothesis is accepted,; if $\varphi_{a}$ is very large, it can be understood that conditional convergence exist under both regime. If $\varphi_{b}$ is too large and $\varphi_{c}$ is not large, it is assumed that there is conditional under regime I, and absolute convergence under regime II. If $\varphi_{c}$ is too large and $\varphi_{b}$ is not large, it is assumed that there is conditional under regime II, and absolute convergence under regime I. When the $H_{1 B}$ hypothesis is accepted; if $\varphi_{b}$ is too large, it may be accepted that conditional convergence exist under regime I while if $\varphi_{b}$ is not too large, it is assumed that absolute convergence exist under regime I. When the $H_{1 C}$ hypothesis is accepted; if $\varphi_{c}$ is too, under this condition it is accepted that large conditional convergence exist under regime II or if $\varphi_{c}$ is not too large then absolute convergence may exist under regime I.

Beyaert and Camacho (2008) developed the following hypotheses using the Caner and Hansen (2001) method to test whether $g_{i t}$ series in Equation (1) and Equation (4) are linear (Çil, Yavuz \& Yılanc1, 2013) : 287-288):

$$
\begin{aligned}
& H_{0}: \delta_{n}^{I}=\delta_{n}^{I I}, \quad \rho_{n}^{I}=\rho_{n}^{I I}, \quad \varphi_{n}^{I}=\varphi_{n}^{I I} \quad i=1,2, \ldots, N . \\
& H_{1}: \delta_{n}^{I} \neq \delta_{n}^{I I} \text { veya } \rho_{n}^{I} \neq \rho_{n}^{I I} \text { veya } \varphi_{n}^{I}=\varphi_{n}^{I I} \quad i \neq 1,2, \ldots, p .
\end{aligned}
$$

Where the hypothesis $H_{0}$ can be rejected, it will be decided that the series is a nonlinear series. In order to test these hypotheses, likelihood function is produced with the help of Equation (7):

$$
\mathcal{L}_{1,2}=-2 \operatorname{Ln}\left(L_{1} / L_{2}\right)
$$

Here $L_{1}$; is the likelihood value of a single regime linear model and $L_{2}$; is the likelihood value of a TAR model with two regimes (Tipoy, 2015).

\section{Findings}

In the study, the linearity of the series of cryptocurrencies returns that is first examined by Caner and Hansen (2001) method, analyzed and the findings are presented in Table 2. 
Table 2: Caner and Hansen (2001) Linearity Test Results

\begin{tabular}{|l|c|c|}
\hline & $\begin{array}{c}\text { Obtained with } \\
\text { Unrestricted } \\
\text { Bootstrap }\end{array}$ & $\begin{array}{c}\text { Obtained with } \\
\text { Restricted Bootstrap }\end{array}$ \\
\hline Probability Value & $0.04^{* *}$ & $0.01^{* *}$ \\
\hline
\end{tabular}

Note: ${ }^{* *}$ indicates that the series is nonlinear at $5 \%$ significance level.

Since the probability values in Table 2 are less than 0.05 , The null hypothesis that indicates the return of cryptocurrencies is linear can be rejected. The existence of a convergence between the returns of cryptocurrencies is examined by Beyaert and Camacho (2008) panel nonlinear TAR unit root test and the findings are presented in Table 3.

Table 3: Beyaert and Camacho (2008) Panel Nonlinear TAR Unit Root Test Results

\begin{tabular}{|l|c|c|}
\hline & Test Statistics & Probability Value \\
\hline Regim I & 2.80 & 0.99 \\
\hline Regim II & $-1.99^{* *}$ & 0.02 \\
\hline
\end{tabular}

Note: ${ }^{*}$ indicates that the series is stationary at $5 \%$ significance level.

According to the results in Table $3, H_{0}$ hypothesis is rejected at $1 \%$ significance level under both regimens and $H_{1 C}$ hypothesis is accepted. In this case, the returns of the crypto currency series are also stationary under regime II. So there is a partial convergence between the returns of the crypto currency. Beyaert and Camacho (2008) method is used to determine which of the conditional or absolute convergence conditions are valid among the returns of the cryptocurrencies and the findings are presented in Table 4.

Table 4: Beyaert and Camacho (2008) Conditional / Absolute Test Results

\begin{tabular}{|c|c|c|}
\hline & Test Statistics & Probability Value \\
\hline$\varphi_{a}$ & $\infty$ & 1.00 \\
\hline$\varphi_{b}$ & $\infty$ & 1.00 \\
\hline$\varphi_{c}$ & $\infty$ & 1.00 \\
\hline
\end{tabular}

According to the results in Table 4 , it is decided that $H_{0}$ hypothesis will be rejected and $H_{1 C}$ hypothesis will be accepted. In Table 4 , it has been decided that partial conditional convergence is the case under regime II as $\varphi_{c}$ is too large $(\infty)$.

In the study, the threshold value is found to be -5.958 . In addition, $36.1 \%$ of the observations are found to be under the first regime. This means that $36.1 \%$ of the returns of the cryptocurrency are less than - 5,958\% (ie, they work under regime I).

In this case, $63.9 \%$ of the observations are greater than $-5.958 \%$ (ie, they work under regime II). As a result, when the findings in Table 3 and Table 4 are reinterpreted, there will be a convergence between the returns of the crypto currency as long as the daily returns of the crypto currency are greater than - 5.958\% (as long as the crypto currency causes a maximum of $5.958 \%$ loss per day) ${ }^{1}$.

\section{Conclusions}

Cryptocurrency eliminates intermediary institutions, minimizes transaction costs and enables fast and reliable transactions. Based on these aspects, it seems to be a solid candidate for taking a much more important place in the economy and finance world of the future. The type of cryptocurrencies that came to the agenda when

${ }^{1}$ The interpretation of this section is based on Çil Yavuz and Yılancı (2013: 289). 
BITCOIN started to be traded on the market on 18.07.2010 increased to 12 in time and there were significant increases in their transaction volume and values. The diversification in cryptocurrencies accelerated especially after 2016 and the values of cryptocurrencies reached the highest level in December 2017. In fact, BITCOIN, which was US $\$ 0.1$ when it was first issued in the market, rose to $\$ 19 \mathrm{~K}$ on December 16,2017 . Similarly, when it was first issued on 10.03.2016, Ethereum was being traded at $\$ 11.75$ and then reached $\$ 1,380$ on 13.01.2018.

Over time, cryptocurrencies that have been legalized by providing a legal basis by major countries, are becoming more widely used around the world. On 19.11.2013, the US Treasury classified BITCOIN as a convertible virtual currency (Kirby, 2018), On 22.10.2015, the Court of Justice of the European Union stated that virtual money trade is exempt from VAT and BITCOIN is a means of payment (Habertürk, 2017a). On 07.04.2017, Japan announced that it accepted cryptocurrencies as legal currency (Habertürk, 2017b). Then, on 25.10.2017 Ukraine was involved in this process and accepted the crypto currency as legal currency (Cyber Bulletin, 2017). All these developments have increased the confidence in cryptocurrencies and also their transaction volume and values.

In this study, the existence of a convergence between the returns of six cryptocurrencies for the period of 30.10.2016-12.05.2019 is analyzed through panel nonlinear TAR unit root test developed by Beyaert and Camacho (2008). The linearity of the return series of cryptocurrencies is examined by Caner and Hansen (2001) method and it was decided that this series was nonlinear. According to Beyaert and Camacho (2008) panel nonlinear TAR unit root test results, it is found out that there is a partial conditional convergence under regime II. In summary, there will be a convergence between the returns of the crypto currency as long as the daily return of the cryptocurrency is greater than $5.958 \%$.

This shows that the cryptocurrencies are not a substitute for each other. Therefore, when creating a portfolio related to these currencies, investors should be careful to choose between Bitcoin, Litecoin, Ripple, Ethereum, Ethereum Classic and Zcash currencies.

Based on the findings obtained from this study, it is seen that cryptocurrencies are spreading rapidly around the world and the activities aimed at putting the legal framework by the countries continue. Therefore, it is necessary for Turkey to accept these money legally and implement the necessary legal arrangements. It can be said that it is time for individuals and financial institutions to add cryptocurrencies to their portfolios, and they need to be careful when choosing between Bitcoin, Litecoin, Ripple, Ethereum, Ethereum Classic and Zcash since they are not full substitute for each other. At this point, the prices of cryptocurrencies, the duration of transactions in the market, their legal recognition and returns may be determinant factors.

\section{References}

Abbott, A., De Vita, G. and Altinay, L. (2012). Revisiting the Convergence Hypothesis for Tourism Markets: Evidence from Turkey Using the Pairwise Approach. Tourism Management, 33(3), 537-544.

Alper, A. E. ve Demiral, M. (2017). Türkiye'nin Turizm Piyasaları İçin Yakınsama Hipotezinin Testi: Fourier Durağanlık Analizi Bulguları. Ömer Halisdemir Üniversitesi İktisadi ve İdari Bilimler Fakültesi Dergisi, 10(4), 205-213.

Bahar, O., Bozkurt, K. and Dogan, B. (2013). Striving for Service Quality: Reality, Problems and Solutions. Social Sciences, 79(1), 7-16.

Barış Tüzemen, Ö. ve Tüzemen, S. (2015). Yakınsama Hipotezi: Balkan Ülkeleri Örneği. BJSS Balkan Journal of Social Sciences, 4(7), 1-9.

Beyaert, A. and Camacho, M. (2008. ). Tar Panel Unit Root Tests and Real Convergence. Review of Development Economics, 12(3), 668-681.

Beyaert, A. ve J. García-Solanes (2009).Real Convergence and Business Cycles: a TAR Panel Unit Root Approach. Preliminary draft, http://www.ub.edu/jei/papers/ BEYAERTGARCIASOLANES.pdf (Erişim Tarihi: 04.06.2019).

Caner, M. and Hansen, B. (2001). Threshold Autoregression with a Unit Root. Econometrica, 69, 1555-1596.

Çil Yavuz, N. C. and V. Yılancı (2013). Convergence in Per Capita Carbon Dioxide Emissions Among G7 Countries: A TAR Panel Unit Root Approach. Environ Resource Econ, 54, 283 - 291. 
M. Özyeşil 11/4 (2019) 3018-3024

Dikmen, F. C. ve Dursun, G. (2018). Unemployment Hysteresis and Convergence: Evidence from Latin American Countries. EconWorld2018 Coference, 23-25 January, Lisbon, Portugal.

Dyhrberg, A.H., Foley, S., Svec, J. (2018). How investible is Bitcoin? Analyzing the liquidity and transaction costs of Bitcoin markets, Economic Letters, 171, 140-143.

Erlat, H. (2012). Türkiye'de Bölgesel Yakınsama Sorununa Zaman Dizisi Yaklaşımı. Türkiye Ekonomi Kurumu, Tartışma Metni, No: 2012/64,

Habertürk (2017a). Bitcoin'de düzenleme yetkisi SPK ve Maliye'de. https://www.haberturk.com/bitcoindeduzenleme-yetkisi-spk-ve-maliyede-1763067-ekonomi, (Erişim Tarihi: 04.06.2019).

Habertürk (2017b). Japonya, bankacılık sistemini değiştiren bir kanun ile Bitcoin ve diğer tüm dijital para birimlerini yasal olarak tanıdı. https://www.haberturk.com/ekonomi/teknoloji/haber/1453992-bitcoinartik-japonyada-yasal\#, (Erişim Tarihi: 04.06.2019).

Kirby, M. (2018). Bitcoin - Virtual Currency. https://www.cga.ct.gov/2018/rpt/pdf/2018-R-0027.pdf, (Erişim Tarihi: 04.06.2019).

Luther W.J.(2016). Cryptocurrencies, Network Effects, and Switching Costs, Contemporary Economic Policy, 34(3), 553-571.

Nakamoto, S., 2008. Bitcoin: A Peer-to-Peer Electronic Cash System. Bitocin.org.

Ozcan, B. and Erdogan, S. (2017). Are Turkey's Tourism Markets Converging? Evidence from the Two-Step LM and Three-Step RALS-LM Unit Root Tests. Current Issues in Tourism, 20(4), 425- 442.

Savacı, S. ve Karşıyakalı, B. (2016). Ülkeler Arası Gelir Yakınsaması Analizi: AB Ülkeleri ve Türkiye. Akdeniz İ.̇.B.F. Dergisi, 33, 237-257.

Siber Bülten (2017). Ukrayna Bitcoin'i yasallaştırıyor, madencilik faaliyetleri artıyor. https://siberbulten.com/bitcoin/ukrayna-bitcoini-yasallastiriyor-madencilik-faaliyetleri-artiyor/, (Erişim Tarihi: 04.06.2019).

Solarin, S. A. (2014). Revisiting the Convergence Hypothesis of Tourism Markets: Evidence from South Africa. Margin: The Journal of Applied Economic Research, 8(1), 77-92.

Solarin, S. A. and Lean, H. H. (2014). Nonlinearity Convergence of Tourism Markets in Seychelles. CurrentIssues in Tourism, 17(6), 475-479.

Tipoy, C. K. (2015). Real Convergence Using TAR Panel Unit Root Tests: An Application to Southern African Development Community. ERSA Working Paper, 536, 1-23.

Yazgan, Ş., Ceylan, R. ve Mollavelioğlu, M. Ş. (2018). Seçilmiş NATO Ülkelerinde Askeri Harcamaların Yakınsaması: Doğrusal Olmayan Birim Kök Testinden Kanıtlar. Akdeniz İ.I.B.F. Dergisi, (37) 118-132. 